\title{
Coming Out as a Library
}

\section{Offering Support to the LGBTQ+ Community During Trying Times}

Daniel Smith, Garrett-Evangelical Theological Seminary

\begin{abstract}
The Styberg Library has offered support to the LGBTQ+ community in a variety of ways. This work stemmed from larger seminary commitments and statements that served as an impetus for the work. As an institution affiliated with the United Methodist Church, we recognized how the current impasse in the denomination had affected our community. In response, we offered ourselves as a place of affirmation and support. First, we curated several displays to highlight relevant resources and services that may be of interest to the queer community. We also created an LGBTQ+ LibGuide to highlight library resources/services and online community resources. Then, we began the process of constructing an archive to document the history of the seminary's LGBTQ+ community after realizing our archive lacked these documents. We continue to explore further ways to extend support. This poster highlighted various aspects of this work.
\end{abstract}

\section{INTRODUCTION}

The Styberg Library at Garrett-Evangelical Theological Seminary strives to be a welcoming place for all, respecting the diverse identities that people bring with them, including gender identity/expression and sexual orientation. We have become more explicit about our support of the LGBTQ+ community over the last couple of years, and we have drafted a library welcome statement (Styberg Library 2019b) for our website to this end. We have also created additional services and collected specific resources to further support this work. We continue to explore further ways to extend support. This poster highlighted various aspects of this work. 


\section{CONTEXT}

To begin, I want to give a little context for the events that preceded our supportive actions. In 1968, the United Methodist Church was formed through a merger. Of course, Methodism had existed long before this, but this merger created an even larger, stronger denomination. By 1972, the church was actively debating what they called "the issue of homosexuality." At the end of the church's quadrennial gathering known as General Conference, new language entered the Book of Discipline, which is the governing text for the denomination. This inserted language formed what is known as the "incompatibility clause," which says in \$304.3 that "the practice of homosexuality is incompatible with Christian teaching" (United Methodist Church 2016). From 1976 to 2016, additional prohibitive language has been inserted into the Book of Discipline, like prohibitions against ordaining LGBTQ+ clergy, marrying same-gender couples, or supporting LGBTQ+ groups. Groups and individuals have been trying to change the church's stance since very early and, in 2019, a very contentious special General Conference was called to specifically address "the issue of homosexuality.” As you can imagine, the atmosphere at the seminary was quite tense during this time and, after the conference, which added further restrictions, our community was left feeling lost, disappointed, angry, confused, and so much more. As an institution affiliated with the United Methodist Church, we recognized how the current impasse in the denomination had affected our community. In response, we offered ourselves as a place of affirmation and support. Along with the seminary, we wanted to openly show support for the LGBTQ+ community, particularly our students. We have continued to build upon our initial response. The poster detailed some of the ways that we have done this.
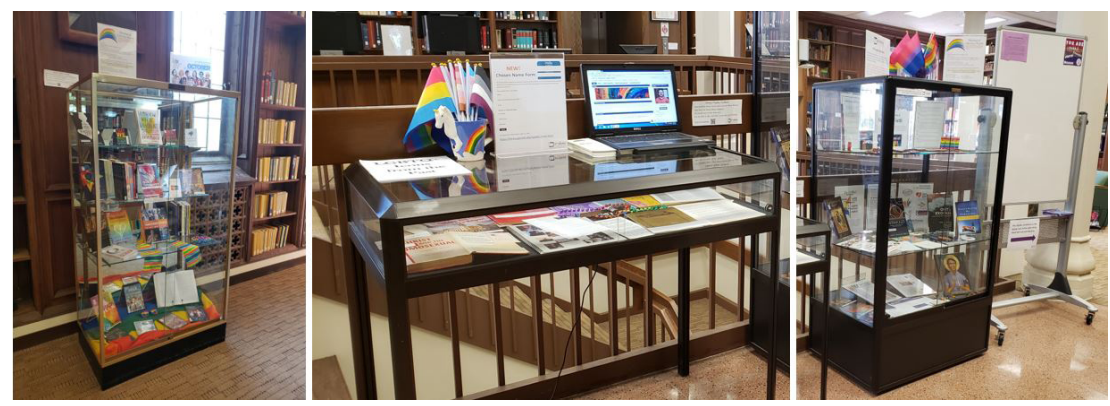
OUR RESPONSE

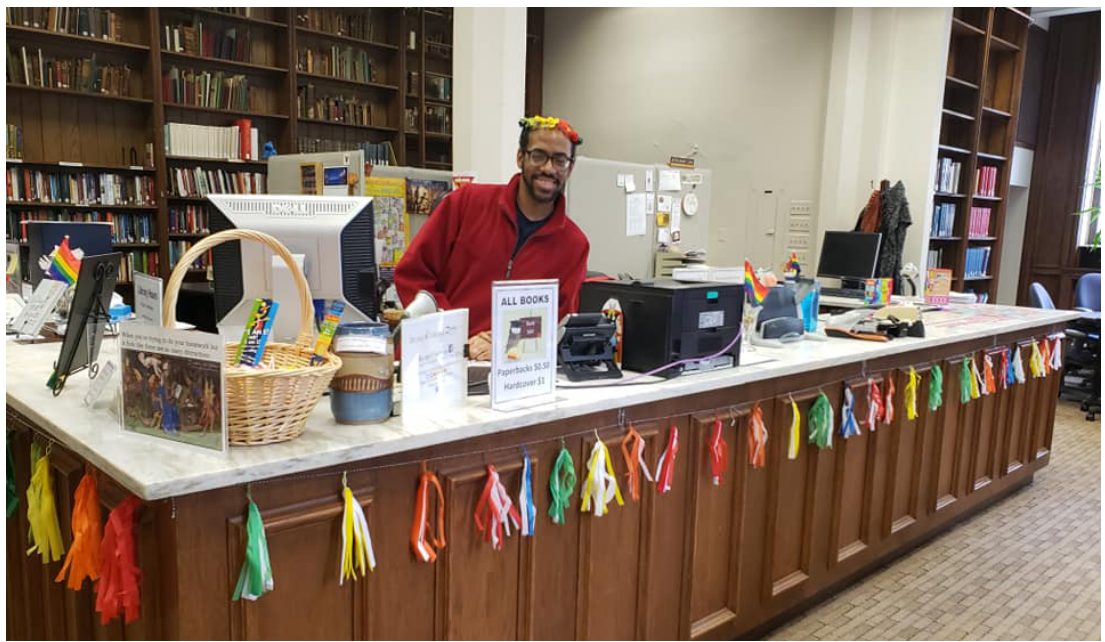

As soon as the conference was over, we decorated the library with rainbows and symbols of pride. This included resources for students to creatively express themselves with art supplies.

We also created a special display of LGBTQ+ materials from our collection. Since then, we have had at least two other LGBTQ+ specific displays for events like Pride month in June and LGBTQ+ History Month in October. We have also endeavored to include LGBTQ+ authors in other monthly displays throughout the year.

Before the conference, we had planned to create an LGBTQ+ LibGuide (Styberg Library 2019a),

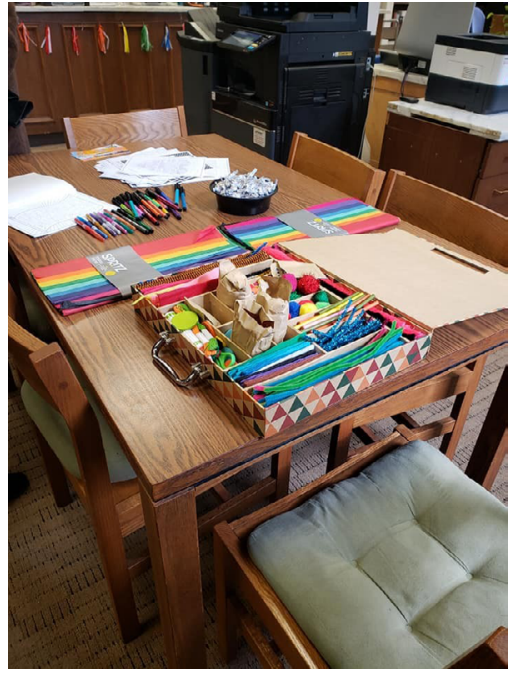
and it was in the works. By the end of the conference, we decided that it was time to share it with our community. It showcased many LGBTQ+ library resources as well as other online resources. We continue to revise and add to it as new items are added to the collection and when we discover new online resources. We also regularly feature new LGBTQ+ resources in our "new arrivals” LibGuide. 
These items are featured in a special area shelving next to our main entrance and are usually quickly checked out by our patrons.

In October 2019, we decided to celebrate LGBTQ+ History Month in conjunction with Theological Libraries Month. We created a display of materials from the collection, which included special archival materials that showcased the seminary's LGBTQ+ history. This celebratory month also featured a discussion with a queer professor and alum who share their research and experience as LGBTQ+ members of the seminary. This was a very moving experience for the seminary community.

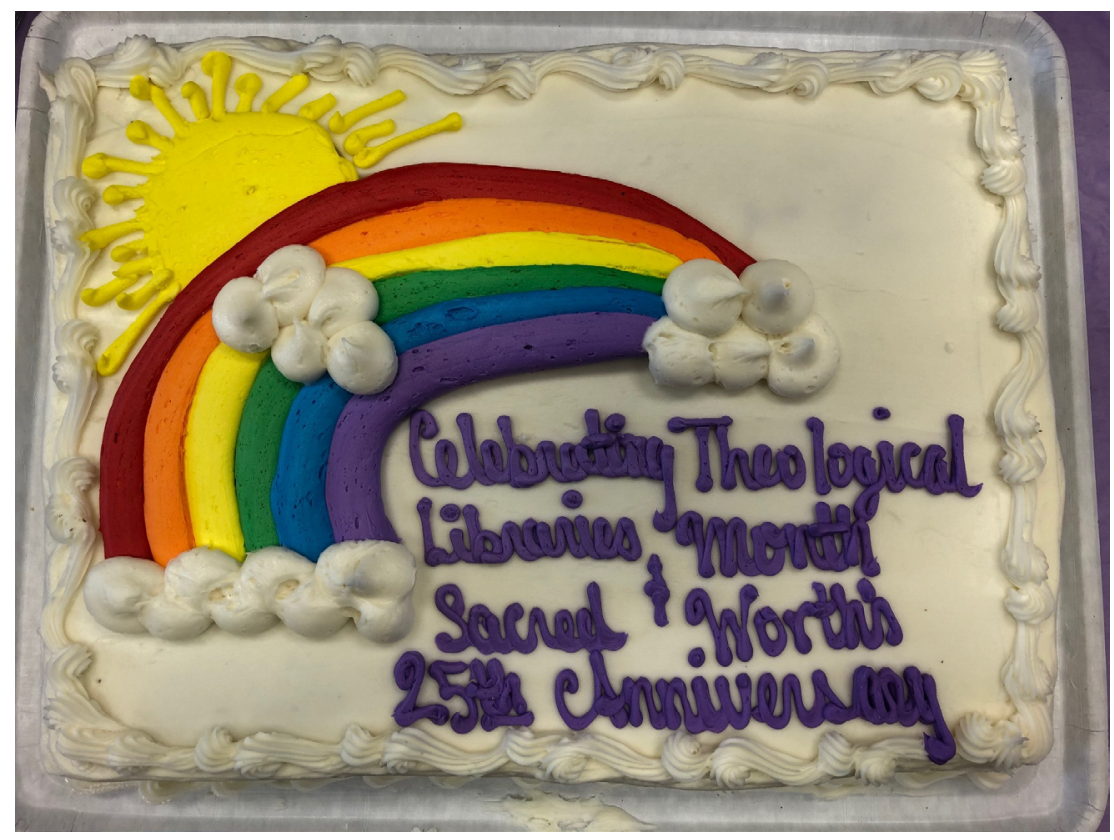

In the process of planning for our celebration, we wanted to find information about the seminary's LGBTQ+ history but quickly realized that our institutional archive was sorely lacking in this regard. We reached out to seminary friends to see if they knew someone who might be able to help expand this collection, and one name was shared by several folks. We contacted this alum and learned that she was a part of the founding of the seminary's first LGBTQ+ student group, which became known as Sacred Worth. This group continues today, and we were able to celebrate its 25th anniversary last year. In fact, this alum was recently honored as a distinguished alum. 


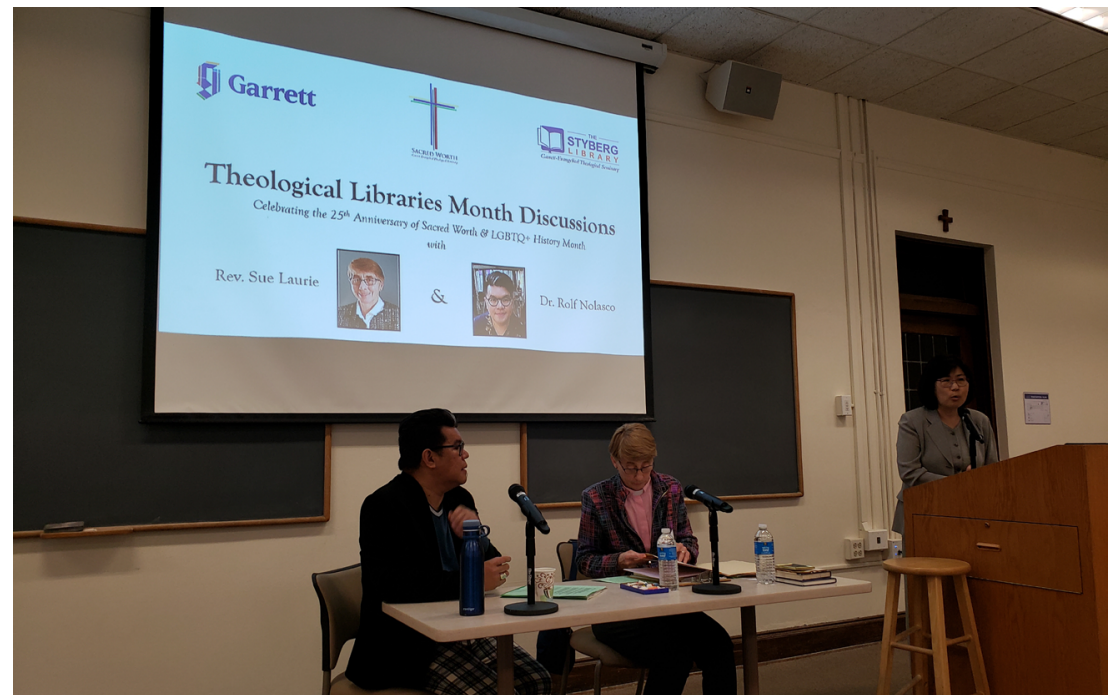

Overall, this work would not have been possible without key partnerships with alums and groups like Sacred Worth. They helped us publicize this event, and they contributed to the displays. We are very grateful for this continued collaboration and look forward to what the future will bring.

We have also updated our services and polices to better support the LGBTQ+ community. All library restrooms have been converted to be single-use and all-gender. We created a library welcoming statement that specifically welcomes people of all sexual orientations and gender identities:

The Styberg Library welcomes and serves all persons, respecting the many diverse identities that they bring with them, including, but not limited to, ability, age, class, gender identity/expression, national origin, sexual orientation, race, and religion. The Library is committed to serving everyone professionally, hospitably, and equitably as we work to fulfill the mission and goals of the Library and Seminary. The Library strives to provide a positive, encouraging environment that makes everyone feel welcome and therefore better able to pursue their academic studies.

Finally, we created a form (Styberg Library 2020) that allows patrons to share their chosen name with us so that all library correspondence uses their chosen name.

We have promoted our resources and events in a variety of ways, and we continue to do so. For us, Facebook, the seminary newsletter, targeted emails, and flyers have been instrumental. Of course, word of mouth has been hugely successful as well. 
Sacred Worth at Garrett-Evangelical Theological

Seminary is at The Styberg Library.

October 7 at 8:33 PM - 9

We post frequently about our library ... but check out a recent option made available to all students!

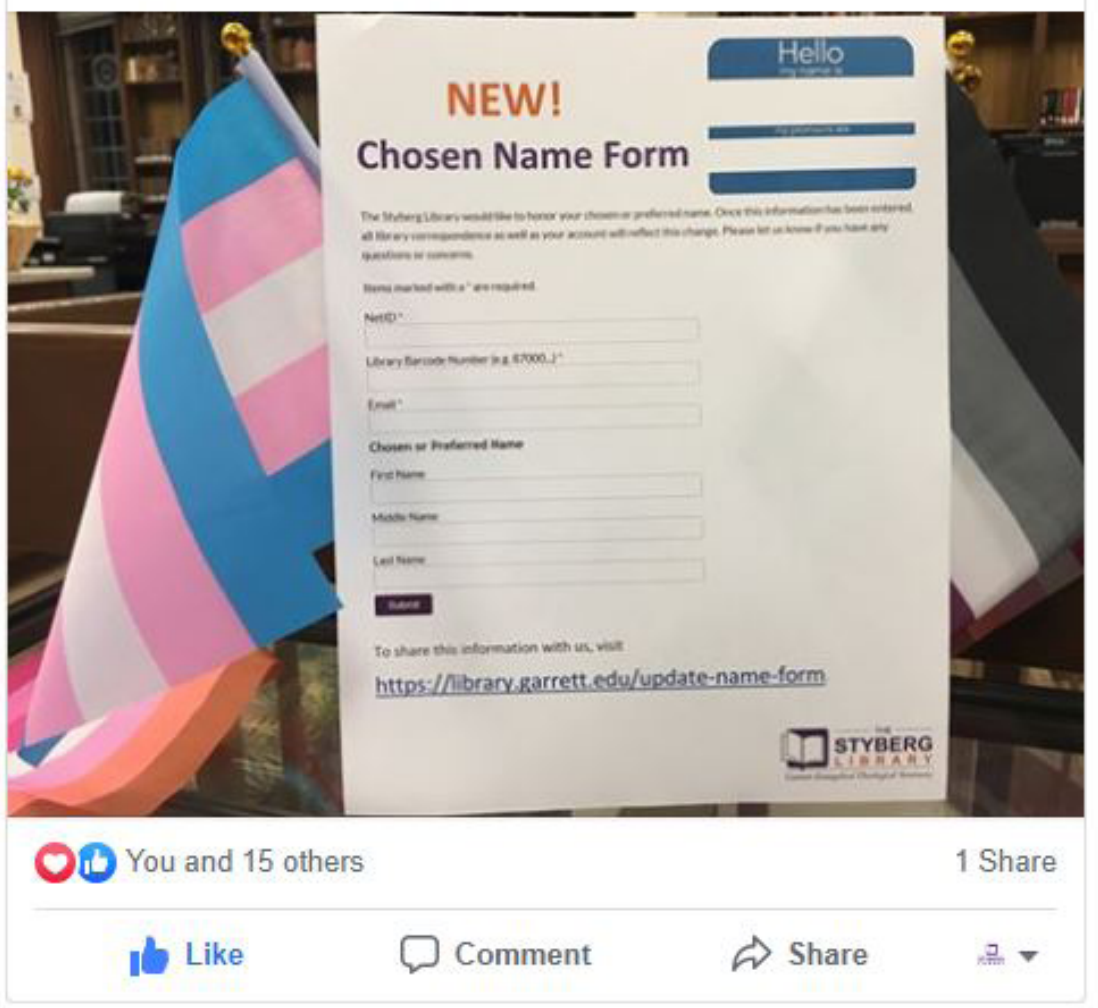

The seminary community has repeatedly expressed its thanks for our supportive work, and we are so glad to be a small part of making the seminary a welcoming, hospitable place for the LGBTQ+ community.

To see more photos and examples of our support, visit bit. ly/3eDCGTe. 


\section{RESOURCES}

There are many ways that you can become a welcoming and supportive library. For additional information about how to welcome the LGBTQ+ community, see these excellent resources:

- American Library Association. 2015. "Open to All: Serving the GLBT Community in Your Library.” www.ala.org/rt/sites/ala.org. rt/files/content/professionaltools/160309-glbtrt-open-to-all-toolkit-online.pdf.

•- _ 2010. "Intellectual Freedom.” www.ala.org/ aboutala/governance/policymanual/updatedpolicymanual/ section2/53intellfreedom. (See B.2.1.16.)

- _ n.d. "Libraries Respond: Services to LGBTQ+ People." www.ala.org/advocacy/diversity/librariesrespond/ServicesLGBTQ.

- Ciszek, Matthew P. 2015. "The Rainbow Connection: Reference Services for the LGBT Community in Academic Libraries.” In Rethinking Reference for Academic Libraries: Innovative Developments and Future Trends, edited by Carrie Forbes and Jennifer Bowers, 35-50. London: Roman \& Littlefield.

- Symons, Ann and John Freeman. 2015. "Serving Everyone: Welcoming the LGBT Community.” American Libraries, June 24, 2015. americanlibrariesmagazine.org/2015/06/24/serving-everyone.

\section{The Styberg Library \\ October 11, $2019 \cdot 0$}

Happy National Coming Out Day! We recognize the historic/personal importance of this day and this continual act. Sharing ourselves is a sacred act, one that is oftentimes very difficult or impossible. Please know that we celebrate you, wherever you find yourself on this journey. Here are a few newer resources about coming out that we have in our collection.

Cantorna, Amber. Refocusing My Family: Coming Out, Being Cast Out, and Discovering the True Love of God. Minneapolis, MN: Fortress Press, 2017.

BR 1725 .C367 A3 2017

Cantorna, Amber. Unashamed: A Coming-out Guide for LGBTQ Christians. Louisville, KY: Westminster John Knox Press, 2019.

BV 4596. G38 C36 2019

Oliveto, Karen P. Our Strangely Warmed Hearts: Coming out into God's Call. Nashville, TN: Abingdon Press, 2018.

BY 75. H6 04382018

Robertson, Brandan, Meléndez Rivera, Lisbeth, and Tolton, Joseph. Our Witness: The Unheard Stories of LGBT Christians. Eugene, OR: Cascade Press, 2018. 


\section{WORKS CITED}

Styberg Library. 2019a. "LGBTQ+ Resource Guide.” guides.garrett. edu/lgbtq.

—. 2019b. "Welcome \& Mission.” library.garrett.edu/about/ welcome-mission.

—_. "Update Name Form.” 2020. library.garrett.edu/update-nameform.

United Methodist Church. 2016. The Book of Discipline of the United Methodist Church. Nashville, TN: Abingdon Press. 